\title{
Strategi Bauran Promosi dalam Sosialisasi Lagu Anak: Studi Kasus Album Penyanyi Cilik Naura
}

\author{
Dwi Okta Renanda \\ Program Pascasarjana Institut Seni Indonesia Yogyakarta \\ dwioktarenanda@gmail.com
}

\begin{abstract}
Abstrak
Perkembangan lagu anak di Indonesia mengalami dinamika yang berbeda dari tahun ke tahun. Era 90-an merupakan puncak dimana lagu anak mendapat perhatian yang lebih dari masyarakat Indonesia. Namun kondisi tersebut berbeda dengan keadaan lagu anak sekarang. Sudah tidak banyak lagi penyanyi-penyanyi cilik yang tampil di televisi dan berkurangnya lagu-lagu yang sesuai untuk anak yang kaya akan pesan pendidikan dan nasionalis. Hal ini dikarenakan sudah tidak banyak label rekaman yang memberikan wadah bagi penyanyi cilik dan adanya anggapan bahwa lagu anak kurang laku. Objek penelitian ini adalah album penyanyi cilik Naura dengan topik strategi promosi dan sosialisasi lagu anak. Penelitian ini bertujuan untuk mengkaji strategi bauran promosi album penyanyi cilik Naura dan mengetahui tanggapan masyarakat terhadap album penyanyi cilik Naura. Pendekatan yang dilakukan dalam penelitian ini adalah metode kualitatif dengan data tambahan sebagai pelengkap dari data kuantitatif berupa pemaparan presentase. Data kualitatif didapat dari 3 orang narasumber dan data kualitatif diperoleh dari 34 responden yang merupakan followers Instagram Naura. Hasil yang diperoleh, manajemen Naura menggunakan semua alat bauran promosi, meliputi periklanan, promosi penjualan, publisitas, penjualan perseorangan dan pemasaran langsung. Sedangkan alat promosi utama yang digunakan adalah pemasaran langsung yang difokuskan pada penggunaan media sosial. Hal ini disebabkan karena mayoritas peggemar Naura adalah anak-anak dan remaja yang memiliki akun media sosial.

Kata kunci: lagu anak, sosialisasi, bauran promosi
\end{abstract}

\begin{abstract}
The development of children's songs in Indonesia experienced different dynamics from year to year. The 90's is the peak where the children's song gets more attention from the people of Indonesia. But the condition is different from the state of the child's song now. There are not many singers-singers who appear on television and reduced the appropriate songs for children who are rich in educational and nationalist messages. This is because there are not many record labels that provide a container for the little singers and the assumption that the child's song is less salable.The object of this research is Naura little singer album with the topic of promotion strategy and socialization of children song. This study aims to examine the promotion mix strategy of Naura's little singer album and to know the public response to Naura's little singer album. The approach taken in this research is qualitative method with additional data as complement of quantitative data in the form of presentation of percentage. Qualitative data were obtained from 3 resource persons and qualitative data were obtained from 34 respondents who were followers Instagram Naura. The results obtained, Naura's management uses all promotional mix tools, including advertising, sales promotion, publicity, individual sales and direct marketing. While the main promotional tool used is direct marketing that is focused on the use of social media. This is because the majority of Naura's fans are children and adolescents who have social media accounts.
\end{abstract}

Keywords: children song, socialization, promotion mix 


\section{Pendahuluan}

Dunia seni musik di era ini terlihat ada dua kutub yang bertentangan sekaligus berjalin di dalam masyarakat, yaitu musik sebagai pengembangan seni di lingkungan tertentu atau biasa disebut dengan istilah seni untuk seni dan musik sebagai seni komersial dalam masyarakat atau sosial (Nasbahry \& Indrayuda 2012: 166). Musik tidak hanya berfungsi sebagai hiburan saja, dalam dunia pendidikan musik pun sangat berperan khususnya dalam pendidikan anak. Anak-anak lebih mudah menerima dan merekam suatu hal melalui lagu, misalnya untuk menghafal alfabet, bagian tubuh dan lain.

Pada saat ini, musik komersial di Indonesia didominasi oleh lagu-lagu dewasa. Jika di era 90-an tiap label rekaman menganggap album anak adalah kesempatan yang menguntungkan, kini album anak dianggap tidak profit, serta banyaknya pembajakan di era digital. Label yang bertahan hingga kini hanya label-label rekaman kelas internasional seperti Sony Music Indonesia yang mana lagunya didominasi oleh lagu-lagu dewasa dan jauh lebih profit.

Saat ini kondisi dalam industri musik lagu anak-anak adalah kebalikan dari era ' 80 -an hingga '90-an. Bens Leo dalam wawancara CNN Indonesia yang dipublikasikan pada 10 Maret 2016 menyebutkan bahwa saat ini major label sudah jarang yang bersedia memproduksi lagu anak dan sudah lama tidak mengakomodasi lagu anak. Dengan demikian untuk memproduksi album anak tidak bisa bergantung pada major label. Jika orang tua memiliki modal yang cukup, maka orang tua bisa memproduksi lagu anak namun secara indie. Ini sudah berlangsung sejak lama dan berhasil. Salah satunya adalah Tasya Kamila. Saat itu Tasya membuat album yang berisi lagu anak-anak karangan A.T Mahmud dan diaransemen oleh Dian H.P.

Folkest dan Lacy (2001: 105) menyebutkan bahwa dalam perkembangan industri musik terbagi menjadi dua kelompok, yaitu musik dari kalangan musisi major dan minor atau biasa disebut dengan indie. Musik dari kalangan major merupakan musik dari para musisi yang terikat kontrak dengan major label. Major label adalah perusahaan rekaman yang dimiliki oleh perusahaan-perusahaan besar seperti Warner Musik Indonesia, Universal Musik Indonesia, Sony-BMG, Nagaswara, Aquarius Musikindo dan lain sebagainya. Musisi dari kelompok ini cenderung mengikuti kemauan pasar dalam bermusik, karena musik yang sudah dikomersilkan akan berubah arahnya, bukan lagi sesuai idealisme musisi, melainkan mengikuti kemauan perusahaan rekaman yang menaunginya. Sedangkan dari kalangan indie, adalah pada musisi yang berkarya secara mandiri dan tidak terikat kontrak dengan major label. Secara harfiah, indie berasal dari kata independen yang berarti para musisi indie tersebut berkarya dan mendistribusikan karyanya secara independen atau mandiri.

Salah satu penyanyi cilik yang mengawali karirnya malalui indie adalah Naura yang sekarang sudah tergabung dalam major label Trinity Production. Adyla Rafa Naura Ayu atau yang lebih akrab dipanggil Naura hadir meramaikan pasar musik anak-anak Indonesia sejak 2014 lalu. Naura merilis album perdana yang berjudul "Dongeng" serta album yang kedua pada tahun 2015 berjudul "Langit Yang Sama". Album "Langit Yang Sama" mengembalikan esensi album anak-anak sebagaimana mestinya. Lagu-lagu Naura mengedepankan tema keseharian yang bermuatan edukasi serta sarat selipan pesan moral pada setiap lagunya. 
Dalam sebuah penciptaan karya tentu membutuhkan proses dan strategi khusus agar karya dapat sampai di penikmat lagu anak itu sendiri. Pencapaian sebuah album musik membutuhkan sumber daya yang besar, dari manajemen yang baik, pembiayaan yang berkelanjutan, kualitas musisi yang bagus dan juga strategi pemasaran yang tepat. Pemasaran adalah salah satu faktor yang memiliki peranan penting untuk mencapai tujuan yang diinginkan dalam penjualan album. Posisinya bisa disebut sebagai perantara antara lagu-lagu yang ada dalam album dengan pendengar dalam melakukan transaksi untuk memuaskan kebutuhan dan keinginan dari penikmat lagu. Di dalam pemasaran ada salah satu elemen yang sangat penting yaitu promosi. Menurut Alma (2006 : 179) dalam bukunya Manajemen Pemasaran dan Pemasaran Jasa disebutkan bahwa promosi adalah sejenis komunikasi yang memberi penjelasan dan meyakinkan calon konsumen mengenai barang dan jasa dengan tujuan untuk memperoleh perhatian, mendidik, mengingatkan dan meyakinkan calon konsumen. Untuk menjalankan promosi yang efektif, maka berbagai jenis promosi harus ditempuh atau biasa yang disebut dengan bauran promosi atau promotion mix.

Menurut Tjiptono (2002: 222) pengertian bauran promosi sebagai berikut, bauran promosi berkaitan dengan upaya untuk mengarahkan seseorang agar dapat mengenal produk perusahaan lalu memahaminya, berubah sikap, menyukai, yakin kemudian membeli dan selalu ingat akan produk tersebut. Sedangkan menurut Kotler (2009 : 77), bauran promosi adalah perpaduan dari iklan, penjualan pribadi, promosi penjualan dan hubungan masyarakat yang dipergunakan perusahaan untuk mencapai tujuan pemasaran. Kotler menyatakan bahwa unsur bauran promosi terdiri atas lima perangkat utama, yaitu advertising, sales promotions, publicity/pubic relations, personal selling, dan direct marketing.

Banyaknya pesaing di industri musik, terutama lagu-lagu dewasa yang muncul saat ini tentu akan memaksa setiap manajemen untuk berfikir strategis dalam menjaga keberlanjutan karyanya. Peran orang tua pun sangat penting dalam berlangsungnya lagu anak. Pengelolaan menjadi poin yang harus diperbaiki untuk mensosialisasikan lagu anak. Baik acuan yang tepat untuk membuat lagu anak, pemanfaatan mediamassa dan menghimbau seniman khususnya musisi Indonesia untuk menggalakkan lagu anak yang semakin berkurang.

\section{LANDASAN TEORI}

\section{Penelitian Terdahulu}

Beberapa penelitian yang digunakan sebagai acuan adalah penelitian yang berkaitan tentang lagu anak yaitu penelitian yang dilakukan oleh Fortunata Tyasrinestu (2014) yang bertujuan untuk mengetahui karakteristik lirik dan karakteristik musikal pada lagu anak. Lalu penelitian yang dilakukan oleh Ana Rosmiati (2014) yang bertujuan untuk mengkaji pemaknaan lagu dolanan anak dan menganalisis dampak lagu dolanan terhadap anak. Selain penelitian yang relevan tentang lagu anak, acuan lain adalah penelitian yang berkaitan tentang bauran promosi yaitu penelitian yang dilakukan oleh Chandra Eka Privandani (2016) tentnang komunikasi pemasaran pada album band indie dengan analisis bauran promosi. Terakhir, penelitian oleh Michael N. Lontoh (2016) yang bertujuan untuk mengetahui keputusan pembelian pada dealer mobil dengan 5 variable bauran promosi yaitu periklanan, promosi penjualan, publisitas, penjualan perseorangan dan pemasaran langsung. 


\section{Sosialisasi}

Menurut Vembriarto dalam Airlangga (2013: 9), menyebutkan sosialisasi adalah sebuah proses belajar yaitu proses akomodasi dengan mana individu menahan, mengubah impuls-impuls dalam dirinya dan mengambil cara hidup atau kebudayaan masyarakatnya. Dalam proses sosialisasi itu individu mempelajari kebiasaan, sikap ide-ide, pola-pola, nilai dan tingkah laku, dan standard tingkah laku dalam masyarakat yang ditempati.

\section{Bauran Promosi (Promotion Mix)}

\section{Periklanan (Advertising)}

Menurut Kotler dan Armstrong (2012: 454) iklan adalah segala bentuk penyajian dan promosi ide, barang atau jasa secara nonpersonal oleh suatu sponsor tertentu yang memerlukan pembayaran. Menurut Kotler (2009: 210), suatu iklan memiliki sifat-sifat sebagai berikut:

a. Public Presentation, iklan memungkinan setiap orang menerima pesan yang sama tentang produk.

b. Pervasiveness, pesan iklan yang sama dapat diulang-ulang untuk memantapkan penerimaan informasi dan memungkinkan pembeli dapat membandingkan pesan dari berbagai pesaing.

c. Amplified Expresiveness, iklan mampu mendramatisasi perusahaan dan produknya.

d. Impersonality, iklan tidak bersifat memaksa khalayak untuk memperhatikan dan menanggapinya.

2. Promosi Penjualan (Sales Promotions)

Kotler dan Armstrong (2009: 270) menjelaskan bahwa promosi penjualan adalah insentif jangka pendek untuk mendorong pembelian atau penjualan sebuah produk atau jasa. Indikator-indikator promosi penjualan diantaranya adalah:

a. Frekuensi promosi adalah jumlah promosi penjualan yang dilakukan dalam suatu waktu.

b. Kualitas promosi adalah tolak ukur seberapa baik promosi penjualan dilakukan.

c. Kualitas promosi adalah nilai atau jumlah promosi penjualan yang diberikan konsumen.

d. Waktu promosi adalah lamanya promosi yang dilakukan oleh perusahaan.

e. Ketepatan sasaran promosi merupakan faktor yang diperlukan untuk mencapai target.

\section{Public Relation/Publicity}

Publisitas merupakan pemanfaatan nilai-nilai berita yang terkandung dalam suatu produk untuk membentuk citra produk yang bersangkutan. Dalam praktiknya, publisitas tidak lepas dari fungsi utamanya, yaitu hubungan dengan pers, publisitas produk, komunikasi korporat, melakukan lobi, dan konseling. Ukuran keberhasilan publisitas/hubungan masyarakat menurut Saladin (2003: 148) antara lain:

a. Penampilannya: Dengan menghitung jumlah penampilan di media.

b. Perubahan kesadaran: Namun memerlukan survei variabel sebelum dan sesudah kampanye.

4. Penjualan Perseorangan (Personal Selling)

Personal Selling merupakan salah satu cara untuk mempengaruhi calon pembeli. Dengan terjadinya komunikasi dua arah yang memungkinkan adanya interaksi secara langsung antara 
dan pemasar calon konsumen. Tjiptono (2010: 5) mengungkapkan sifat-sifat personal selling adalah sebagai berikut:

a. Personal Confrontation, yaitu hubungan yang hidup, langsung, dan interaktif antara dua orang.

b. Cultivation, yaitu sifat yang memungkinkan berkembangnya segala macam hubungan.

c. Response, yaitu situasi yang mengharuskan pelanggan untuk mendengar, memperhatikan.

5. Pemasaran Langsung (direct marketing)

Pemasaran langsung merupakan sistem pemasaran yang menggunakan berbagai media untuk berinteraksi langsung dengan konsumen dan untuk mendapatkan respon secara langsung dari konsumen. Sifat pemasaran langsung menurut Kotler yang diterjemahkan oleh Teguh, dkk (2002: 645), yaitu:

a. Nonpublik, yaitu pesan biasanya ditujukan kepada orang tertentu.

b. Disesuaikan, yaitu pesan dapat disiapkan untuk menarik orang yang dituju.

c. Terbaru, yaitu pesan dapat disiapkan dengan snagat cepat.

d. Interaktif, yaitu pesan dapat diubah tergantung pada tanggapan orang tersebut.

\section{Lagu Anak}

Lagu anak menurut Endraswara dalam Kusumawati (2013: 4) adalah lagu yang bersifat riang dan mencerminkan etik luhur. Lagu anak merupakan lagu yang biasa dinyanyikan anakanak, sedangkan syair lagu anak-anak berisi hal-hal sederhana yang biasanya dilakukan oleh anak-anak. Syair lagu anak biasanya bercerita tentang cinta kasih pada sesama, Tuhan, ayahibu, kakak-adik, keindahan alam, kebesaran Tuhan yang ditulis dengan bahasa yang sederhana sesuai dengan alam pikir anak-anak.

\section{Metode Penelitian}

\section{Deskripsi/Jenis Penelitian}

Pendekatan penelitian yang digunakan dalam penelitian ini adalah kualitatif dengan kombinasi data kuantitatif sebagai data pendukung. Data kualitatif ditujukan untuk memperoleh validitas data berdasarkan variabel periklanan, promosi penjualan, publisitas, penjualan perseorangan, pemasaran langsung, dan sosialisasi dalam album Naura, melalui wawancara atau indept interview dengan narasumber yang dipilih. Penelitian ini mengambil beberapa lokasi dikarenakan narasumber yang berbeda lokasi. Pertama yaitu di Studio Backbeat, Jakarta Selatan terhadap produser dan pencipta lagu di album Naura. Wawancara selanjutnya di area Yogyakarta untuk menemui expertise di bidang musik yaitu dengan pengamat musik Bens Leo dan narasumber lain adalah para konsumen atau penikmat album Naura yang berada di Yogyakarta. 


\section{Subjek Penelitian}

Subjek penelitian terdiri dari tiga kelompok yaitu stakeholder, expertise dan masyarakat. Berikut ini tabel keterangan mengenai subjek penelitian.

Tabel 1. Subjek Penelitian

\begin{tabular}{|l|l|l|l|}
\hline Kelompok & \multicolumn{1}{|c|}{ Nama } & \multicolumn{1}{|c|}{ Kompetensi } & \multicolumn{1}{c|}{ Keterangan } \\
\hline Stakeholder & Simhala Avadana & Musisi & Pencipta lagu, Penata Musik Album Naura \\
\hline & Riafinola Be3 & Penyanyi & Produser Album Naura \\
\hline Expertise & Bens Leo & Pengamat Musik & Pengamat Industri Musik, Jurnalis, promotor artis \\
\hline Masyarakat & Follower Instagram Naura & Penikmat lagu-lagu Naura \\
\hline
\end{tabular}

Keterangan :

1. Riafinola Ifanisari (38 tahun) atau Nola yang merupakan orang tua dari Naura sekaligus produser dari Album Naura. Pertimbangan yang mendasari pemilihan subyek antara lain dikarenakan keinginan Naura untuk terjun ke dunia musik awalnya melalui persetujuan Nola. Segala aktivitas Naura, tawaran kerja sama, pemilihan konten lagu di album adalah berdasarkan inisiatif dan tidak lepas dari pengetahuan, izin, peran Nola.

2. Simhala Avadana (37 tahun) yang berperan sebagai pencipta keseluruhan lagu di album Naura. Pertimbangan yang mendasari pemilihan subyek antara lain dikarenakan awal karir Naura pada single pertamanya sudah ditangani langsung oleh Mhala sampai ke penciptaan album pertama dan kedua. Selain itu Mhala merupakan staf dari PT Trinity Optima Production dan menjabat sebagai Artist and Repertoire (A\&R). A\&R adalah penghubung antara talent dengan label.

3. Bens Leo (65 tahun), yang merupakan narasumber ahli sebagai pengamat musik, wartawan, dan produser. Pertimbangan yang mendasari pemilihan subyek antara lain dikarenakan Bens Leo bisa mengetahui secara menyeluruh perkembangan dan kondisi industri musik di Indonesia

4. Responden dari kalangan masyarakat diambil dari sample followers Instagram Naura sejumlah 34 orang untuk memperoleh data kuantitatif.

\section{Teknik Pengumpulan Data}

Teknik pengumpulan data dalam penelitian ini bersumber dari data primer dan data sekunder. Menurut Lofland dan Lofland (1984: 47) sumber data primer dalam penelitian kualitatif adalah kata-kata (wawancara), tindakan (observasi) dan dokumentasi. Sedangkan data sekunder merupakan berupa bukti, catatan atau laporan historis yang telah tersusun dalam arsip (data dokumenter) yang dipublikasikan dan yang tidak dipublikasikan.

Pengambilan data kuantitatif menggunakan alat bantu Google Form. Google Form atau biasa disebut Google Formulir adalah alat yang berguna untuk membantu merencanakan acara, mengirim survei, memberikan siswa atau orang lain kuis, atau mengumpulkan informasi yang mudah dengan cara yang efisien. Subjek penelitian yang digunakan untuk mendapatkan data kuantitatif adalah para followers akun Instagram Naura. Pengumpulan data dalam penelitian ini menggunakan intrumen penelitian berbentuk kuesioner yang terdiri dari 3 (tiga) bagian, meliputi data demografi responden, pertanyaan mengenai bauran promosi sejumlah, dan pertanyaan tentang sosialisasi. 


\section{Teknik Analisis Data}

Data kualitatif akan dilakukan analisis data yang menggunakan analisis isi. Analisis isi adalah pengujian yang sistematis dan dapat direplikasi dari simbol-simbol komunikasi, dimana simbol ini diberikan nilai numerik berdasarkan pengukuran yang valid, dan analisis menggunakan metode statistik untuk menggambarkan isi, menarik kesimpulan, dan memberikan konteks. Kemudian data kualitatif dan data kuantitatif akan dianalisis secara trianggulasi untuk saling dikonfirmasi isinya.

\section{Analisis dan Pembahasan}

\section{Latar Belakang Album Naura}

Latar belakang diproduksinya album Naura hingga 2 (dua) album yaitu album "Dongeng" dan album "Langit Yang Sama" kronologinya adalah sebagai berikut.

Adyla Rafa Naura Ayu atau yang dikenal dengan panggilan Naura adalah anak pertama dari Nola personil Be3. Dengan bakat musik dan pengalaman musik dari Nola yang diturunkan kepada anaknya menjadi bekal untuk menjadi penyanyi cilik. Nola pun membebaskan anaknya untuk memilih minat dan bakat mana yang akan ditekuni karena Nola menyadari anaknya mempunyai bakat bernyanyi. Anak kelahiran 18 Juni 2005 ini mempunyai keinginan untuk bernyanyi yang disampaikan kepada ibunya saat Naura berusia 5 tahun, namun keinginan tersebut sempat tertunda karena Nola masih sibuk dengan grupnya, Be3. Nola berpesan agar tidak setengah-setengah jika Naura ingin terjun ke industri musik harus latihan sebaik mungkin. Pada usia 7 tahun Naura memaksa ibunya untuk membuat single lagu bersama ibunya.

Nola pun akhirnya bekerja sama dengan pencipta lagu yang merupakan personil Numata, yaitu Mhala untuk membuatkan satu lagu yang berjudul Semesta Cinta dan dinyayikan oleh Naura dan Nola. Awalnya lagu ini diproduksi hanya untuk keperluan pribadi saja dan bukan untuk dijual. Nola hanya mengunggah video klipnya di YouTube. Melalui single yang diunggah ke YouTube itulah Naura dan Nola mendapat banyak respon yang baik dari pendengarnya. Sehingga Nola memutuskan untuk memproduseri anaknya sendiri dan mulai membuat album dengan beberapa permintaan tema lagu dari Naura.

Kehadiran Naura di industri musik anak Indoensia rupanya mendapat respon yang baik, terlihat dari beberapa penghargaan yang diraihnya antara lain: AMI Award untuk Artis Solo Perempuan Anak-anak Terbaik tahun 2016, AMI Award untuk Album Musik Lagu Anakanak Terbaik 2015-2016. Naura pun mempunyai sebutan tersendiri untuk para penggemarnya yaitu Teman Naura. Album "Dongeng" dirilis pada Juni 2014 di Galeri Indonesia Kaya (Grand Indonesia). Pada album ini, produksi secara keseluruhan masih ditangani sendiri secara indie oleh Nola selaku ibu sekaligus produser. 

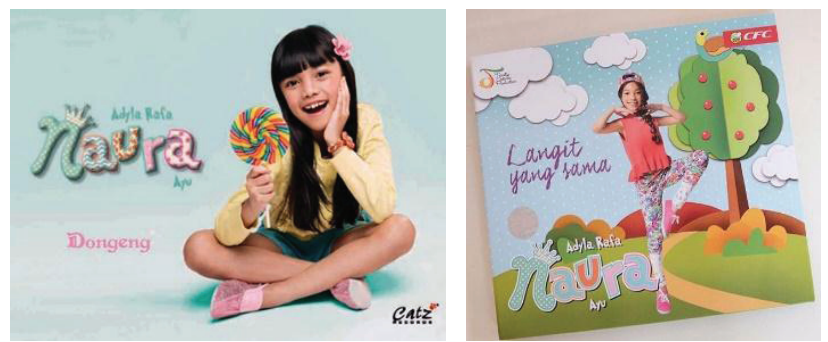

Gambar 1. Cover Album "Dongeng" dan Album "Langit Yang Sama" Sumber: hot.detik.com (diakses pada 15 Mei 2017)

Album ini juga bekerja sama dengan sebuah parenting club/milis parenting yang digagas oleh Mona Ratuliu. Jadi tiap lagu pada album ini dibedah dalam forum ini "mengapa lagulagu pada album dongeng cocok untuk anak". Melihat kesuksesan Naura di album pertamanya, ternyata membuat label meliriknya. Sehingga pada album ke-2 Naura bekerja sama dengan label Trinity Optima Production sebagai executive produser.

\section{Periklanan}

Hasil wawancara terhadap 3 (tiga) narasumber terkait periklanan yang diterapkan dari kegiatan promosi album Naura adalah melalui iklan radio dan televisi. Berikut ini keterangan lengkap terkait periklanan album Naura.

1. Pada periklanan pihak Naura menggunakan media radio dan televisi sebagai media pendukungnya.
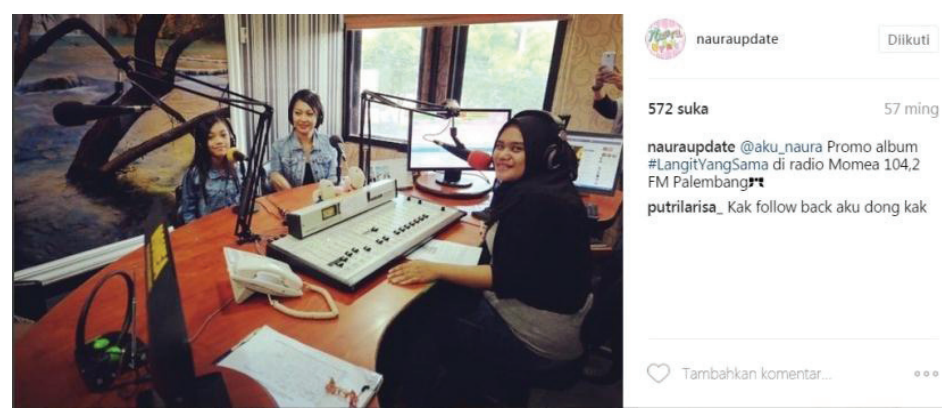

Gambar 2. Promo Album "Langit Yang Sama” di Radio Momea FM Palembang Sumber : Instagram.com/nauraupdate (diakses pada 28 Mei 2017)

2. Sama halnya iklan radio, pada iklan televisi pihak Naura juga tidak secara langsung mempromosikan album musiknya, tetapi penggunaan iklan televisi lebih kepada promosi konser yang akan diselenggarakan Naura.

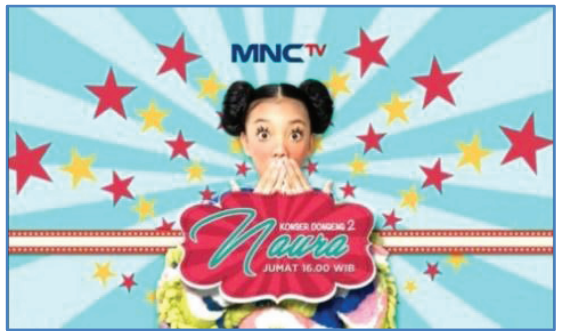

Gambar 3. Cuplikan Iklan Naura di MNCTV; Sumber : YouTube.com (diakses pada 29 Mei 2017) 


\section{Promosi Penjualan}

Hasil wawancara terhadap 3 (tiga) narasumber terkait promosi penjualan yang diterapkan dari kegiatan promosi album Naura adalah melalui pengadaan kuis, adanya edisi khusus, dan pembuatan merchandise Naura. Berikut ini keterangan lengkap terkait periklanan album Naura.

1. Naura memiliki 2 (dua) packaging CD album dan DVD karaoke lagu-lagu Naura. Edisi CD album merupakan kemasan yang ekonomis dengan harga terjangkau, berbentuk CD dan berisi lagu-lagu Naura saja. Namun ada pula kemasan DVD karaoke di album kedua. Edisi ini termasuk edisi eksklusif yang lebih lengkap. Kemasannya berbentuk seperti buku cerita dengan hardcover, agar orang tua bisa memberikan penjelasan isi lagu-lagu melalui buku tersebut.

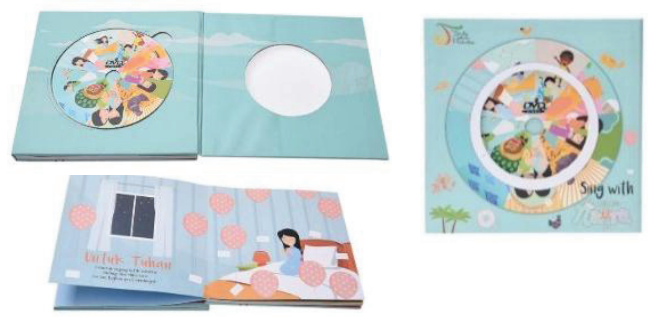

Gambar 4. Kemasan DVD Karaoke "Album Langit Yang Sama” Sumber: blibli.com (diakses pada 15 Mei 2017)

2. Pengadaan kuis berhadiah merupakan salah satu cara promosi penjualan yang diterapkan oleh pihak Naura untuk menarik konsumen lebih banyak. Salah satu contoh kuis yang diadakan adalah sebagai berikut :

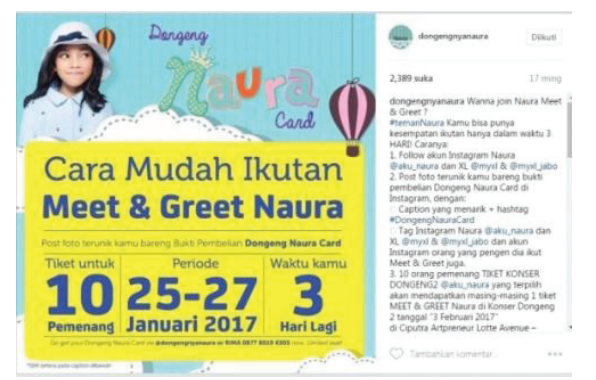

Gambar 5. Kuis "Meet and Great Naura"

Sumber : Instagram.com/dongengnyanaura (diakses pada 28 Mei 2017)

\section{Publisitas/Hubungan Masyarakat}

Hasil wawancara terhadap 3 (tiga) narasumber dan beberapa responden follower Instagram Naura terkait publisitas yang diterapkan dari kegiatan promosi album Naura adalah melalui konferensi pers setiap kali akan ada album baru, event konser, atau produk baru berkaitan tentang Naura.

1. Konferensi pers merupakan cara utama dalam menjalin hubungan dengan pers. Kegiatan ini selalu dilakukan tiap kali akan ada album baru, event konser, atau produk baru berkaitan tentang Naura. Pihak Naura mengundang infotainment, media cetak, media online untuk membantu membuat berita agar tersampaikan ke masyarakat. 


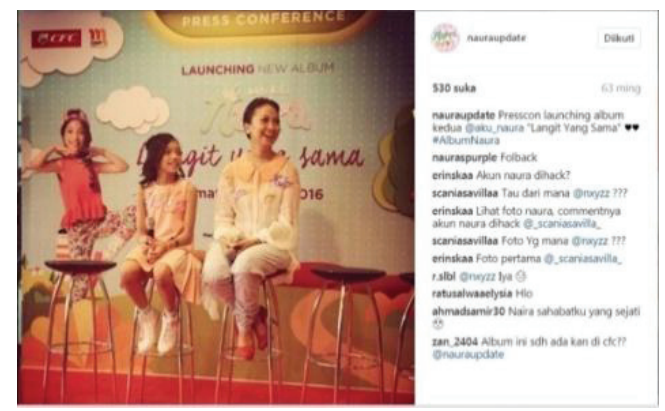

Gambar 6. Konferensi Pers \& Launcing Album "Langit Yang Sama" Sumber: Instagram.com/nauraupdate (diakses pada 28 Mei 2017)

2. Peran public relations atau biasa disebut $P R$ merupakan hal yang penting dalam pembuatan album. $P R$ memiliki optimisme yang kuat dengan produk yang akan dijual pasti memiliki pangsa pasar tersendiri. Selain itu karena adanya faktor biaya promosi yang terbatas dari label rekaman membuat $P R$ mempunyai tugas yang penting dan lebih berat, karena $P R$ harus menguasai medan industri musik dan memiliki kemampuan untuk menciptakan citra yang baik serta karakter (dalam hal ini penyanyi) yang diinginkan oleh pendengarnya.

\section{Penjualan Perseorangan (Personal Selling)}

Hasil wawancara terhadap 3 (tiga) narasumber terkait penjualan perseorangan yang diterapkan dari kegiatan promosi album Naura ditemukan bahwa penjualan perseorangan sempat berjalan pada album pertama yang bersifat indie dan belum masuk ke mayor label. Berikut ini keterangan lengkap terkait penjualan perseorangan dalam album Naura.

Penjualan perseorangan tidak banyak dilakukan dalam album Naura. Penjualan perseorangan hanya sempat terjadi di album pertama "Dongeng" karena di album kedua penjualan sudah ditangani oleh pihak Trinity selaku executive produser. Pada album pertama Nola (produser) sempat melakukan titip edar kepada rekan-rekannya, mitra dan beberapa perkumpulan tentang parenting (milis parenting). Industri musik anak tidak pernah mati. Selain Naura, banyak juga anak-anak yang memenuhi keinginannya tau orang tuanya untuk membuat album anak secara indie.

\section{Pemasaran Langsung (Direct Marketing)}

Dalam kegiatan pemasaran langsung, pihak Naura memaksimalkan pemanfaatan media internet seperti social media dan penjualan online. Social media Instagram merupakan kekuatan utama yang diakui oleh Nola dalam promosi setiap produk dari Naura. Dengan follower akun @aku_naura yang mencapai 673.000 followers (pada Mei 2017) memungkinkan Naura untuk menginformasikan segala jenis aktivitasnya, promosi, atau berinteraksi dengan para penggemarnya. Sebagai contoh, penggunaan Instagram untuk memasarkan tiket "Konser Dongeng 2", hanya dalam waktu 2 hari, tiket sudah terjual habis. Hal ini menunjukkan mayoritas penggemar Naura aktif di Instagram dan lebih sering berinteraksi melalui Instagram. Bens Leo berpendapat bahwa alangkah celakanya jika seseorang yang punya talenta namun tidak menguasai media sosial. Karena menurutnya untuk saat ini promosi melalui media sosial adalah yang paling efektif. Selain melalui toko 
kaset/CD, penjualan album Naura dan merchandise Naura bekerjas ama dengan situs belanja online blibli.com. Hal ini mempermudah terutama pembeli yang mempunyai jarak jauh dari Jakarta. Para pembeli bisa memesan secara online dengan mudah.

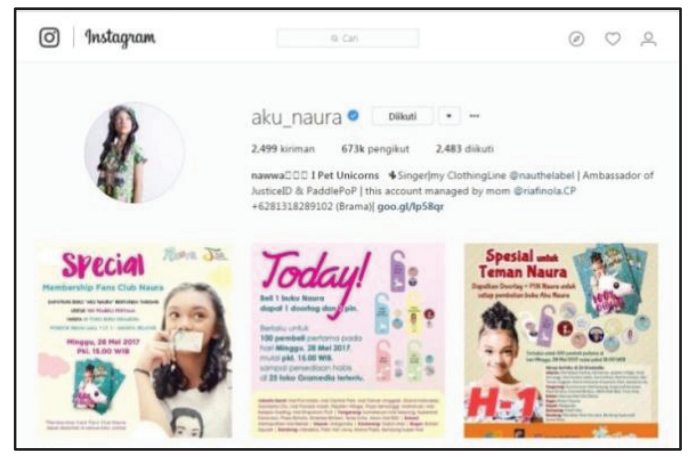

Gambar 7. Akun Instagram Naura mencapai 673.000 followers Sumber : Instagram.com/aku_naura (diakses pada 28 Mei 2017)

\section{Penyajian Data Pendukung Kuantitatif}

Penyajian data kuantitatif pada penelitian ini merupakan data pelengkap dan pendukung untuk mengkonfirmasi hasil data penelitian kualitatif. Oleh karena itu, data kuantitatif tidak diolah secara mendalam dan masih berbentuk persentase saja. Data kuantitatif yang diperoleh dari follower Instagram Naura berikut ini merupakan cross check dari pernyataan-pernyataan yang disampaikan oleh pihak stakeholder sehingga data kualitatif dan kuantitatif dapat dikorelasikan. Pemilihan responeden yang diambil dari Instagram disebabkan karena pihak stakeholder menyatakan media promosi utama yang digunakan adalah melalui Instagram. Kemudian penggemar Naura yang mayoritas berusia 12 tahun sudah menggunakan Instagram.

\section{Analisis Data Demografi Penikmat Lagu Naura}

Berdasarkan data ringkasan pada tabel 2 diketahui bahwa mayoritas karakteristik demografi pendengar album Naura ini adalah pendengar yang berjenis kelamin perempuan, berusia sekitar 10-13 tahun dan berstatus sebagai pelajar Sekolah Dasar (SD).

Tabel 2. Distribusi Karakteristik Demografi Responden

\begin{tabular}{|l|l|l|l|}
\hline Karakteristik & Keterangan & Frekuensi & Persentase \\
\hline \multirow{3}{*}{ Jenis Kelamin } & Perempuan & 32 & $94,1 \%$ \\
\cline { 2 - 4 } & Laki-laki & 2 & $5,9 \%$ \\
\hline \multirow{5}{*}{ Usia Responden } & 10 tahun & 4 & $11,7 \%$ \\
\cline { 2 - 4 } & 11 tahun & 7 & $20,5 \%$ \\
\cline { 2 - 4 } & 12 tahun & 15 & $44,1 \%$ \\
\cline { 2 - 4 } & 13 tahun & 6 & $17,6 \%$ \\
\cline { 2 - 4 } & 16 tahun & 1 & $2,9 \%$ \\
\cline { 2 - 4 } & 20 tahun & 1 & $2,9 \%$ \\
\hline Pendidikan & SD & 24 & $70,5 \%$ \\
\cline { 2 - 4 } & SMP & 8 & $2,9 \%$ \\
\cline { 2 - 4 } & SMA/SMK & 1 & $2,9 \%$ \\
\cline { 2 - 4 } & Perguruan Tinggi & 1 & \\
\hline
\end{tabular}


Analisis demografi responden digunakan untuk menentukan karakteristik responden penelitian, adapun data demografi tersebut dibagi dalam beberapa karakteristik, antara lain;

1. Jenis Kelamin

Jenis kelamin dibagi dalam 2 (dua) kategori yaitu laki-laki dan perempuan. Hasil analisis data dari 34 responden pada gambar ditemukan bahwa 94,1\% responden dengan jenis kelamin perempuan sebanyak 32 orang dan 5,9\% laki-laki sebanyak 2 orang. Hal tersebut karena Naura adalah seorang penyanyi cilik perempuan dan gaya atau style Naura kerap menjadi panutan bagi para anak-anak atau remaja perempuan. Selain itu, pendengar musik akan cenderung mendengarkan penyanyi yang bergender sama karena secara range suara memiliki kesamaan.

2. Usia Responden

Usia responden tidak diberi kategori karena jumlah responden yang relatif tidak banyak dan segmen responden ditujukan kepada anak-anak dan remaja. Hasil analisis data dari 34 orang responden ditemukan bahwa mayoritas penggemar Naura dengan persentase 44,1\% berusia 12 tahun. Hal tersebut mengindikasikan bahwa usia tersebut tergolong sama (seusia) dengan usia Naura yang saat ini berusia 12 tahun (2017). Sesuai dengan pangsa pasar album Naura adalah anak-anak remaja, sehingga untuk pendengar yang berusia 16-20 tahun terhitung jarang.

\section{Pendidikan}

Tingkat pendidikan responden dibagi dalam 4 (empat) kategori yaitu SD (Sekolah Dasar), SMP (Sekolah Menengah Pertama), SMA (Sekolah Menengah Atas) dan Perguruan Tinggi. Hasil analisis dari 34 responden, mayoritas pendengar lagu-lagu Naura adalah para siswa SD (Sekolah Dasar) dengan persentase 70,5\%. Hal ini mengonfirmasi bahwa data usia pendengar lagu-lagu Naura jika dihitung berdasarkan tingkat pendidikan adalah para remaja awal yaitu dengan rentang usia 12-15 tahun. Pada usia tersebut biasanya anak-anak sedang berada di masa perpindahan antara SD dan SMP.

\section{Sosialisasi Lagu Naura}

Pada variabel sosialisasi, data primer diperoleh dari penikmat lagu-lagu Naura, yaitu dengan sampel para follower Instagram akun Naura. Pemilihan responden dari follower Instagram karena, berdasarkan keterangan sebelumnya yang diperoleh dari produser Naura, media promosi utama yang digunakan sejak awal perilisan album Naura adalah melalui Instagram. Oleh karena itu, responden yang menjadi follower Instagram Naura tentunya mengetahui perkembangan Naura. Berikut ini data-data pendukung kualitatif berkaitan dengan Naura.

\section{Persentase Kepemilikan CD Album Naura}

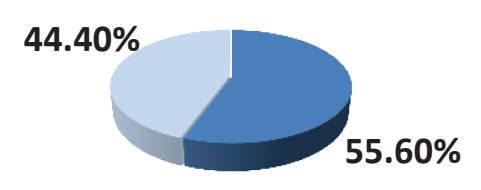
Mempunyai Album Naura
Tidak Mempunyai Album Naura

Gambar 8. Persentase Reseponden yang Memiliki CD Album Naura 
Dari keterangan gambar 8 dapat dilihat bahwa 55,6\% responden yang mengikuti Instagram Naura mempunyai CD Album Naura. Sedangkan 44,4\% responden lainnya tidak mempunyai Album Naura.

Banyaknya media untuk mendengar lagu Naura membuat para penggemarnya tidak harus membeli CD albumnya untuk bisa mendengarkan lagu-lagu Naura. Keping-kepingan CD kini sudah bisa digantikan dengan banyaknya aplikasi musik online, seperti iTunes, JOOX, dan Spotify. Selain itu melalui internet pun para penggemar Naura bisa mengakses lagu-lagu Naura dengan mudah seperti melalui YouTube dan mengunduh via internet adn menyimpannya di ponsel agar lebih praktis. Berikut ini adalah data mengenai cara-cara penggemar Naura memperoleh lagu Naura dengan berbagai media.

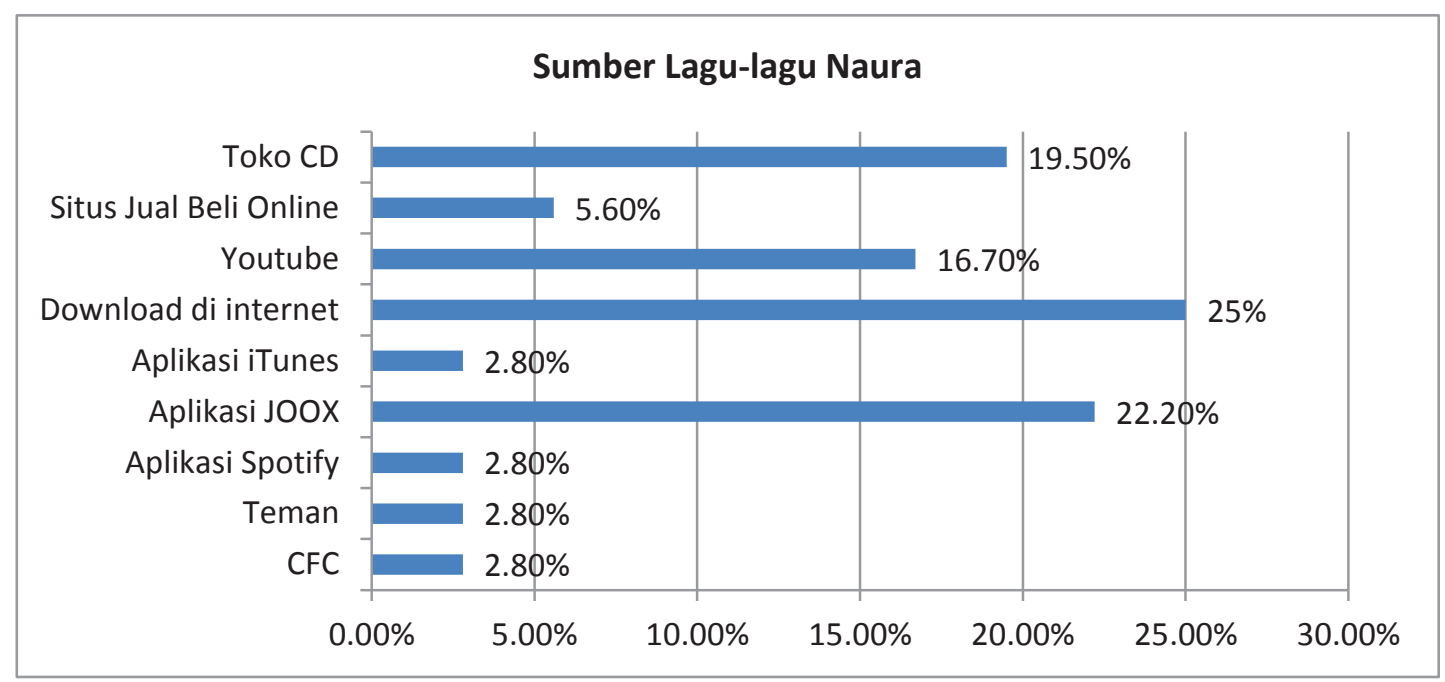

Gambar 9. Persentasi Cara Responden Mendapat Lagu-lagu Naura

Dari gambar 9 di atas, secara umum dapat dilihat bahwa ada 9 cara bagi para penggemar Naura untuk mendapatkan lagu-lagu Naura dari yang berbayar sampai dengan cara gratis. Cara yang paling banyak diambil adalah dengan download lagu melalui internet yaitu dengan persentase $25 \%$ responden. Akses ini cukup mudah karena di Indonesia sendiri tidak ada larangan untuk men-download secara gratis melalui situs-situs musik di internet. Diurutan kedua yaitu penggunaan aplikasi JOOX dengan persentase sebesar 22,2\% responden. JOOX adalah aplikasi yang dapat digunakan di ponsel Android atau pun Apple, yang menyediakan berbagai macam lagu dari seluruh dunia dan dapat didengarkan secara streaming online. Sedangkan yang memperoleh dari toko CD terdapat $19,5 \%$ responden.

Dalam hal pemasaran album Naura, pihaknya juga bekerja sama dengan situs pembelian online yaitu blibli.com. Dan dari survei didapat data bahwa 5,6\% responden pernah membeli CD Naura melalui situs tersebut. Sedangkan akses lainnya yang cukup jarang dilakukan untuk mendapat lagu-lagu Naura adalah melalui aplikasi iTunes, aplikasi Spotify, kerabat atau teman dan di CFC (California Fried Chicken).

\section{Analisis Bauran Promosi}

\section{Periklanan}

Dari gambar 10 dapat ditunjukkan bahwa 90,2 \% responden pernah menyaksikan iklan Naura di televisi, 41,2\% responden pernah mendengar iklan Naura di radio, 70,6\% responden 
pernah membaca iklan Naura di media cetak, dan 55,9\% responden pernah melihat iklan Naura melalui poster. Dari keterangan tersebut dapat ditarik kesimpulan bahwa penikmat lagu-lagu Naura lebih banyak menyaksikan iklan Naura melalui media tevelisi dan seiring perkembangan media komunikasi, pendengar radio kini semakin berkurang karena dari data responden yang diperoleh, iklan melalui radio memiliki persentase paling kecil untuk didengar oleh penikmat lagu-lagu Naura. Dengan pemaparan demikian maka dapat disimpulkan bahwa respon/jawaban penggemar Naura sesuai dengan pernyataan dari pihak stakeholder yang mengedepankan penggunaan iklan melalui media televisi dan radio.

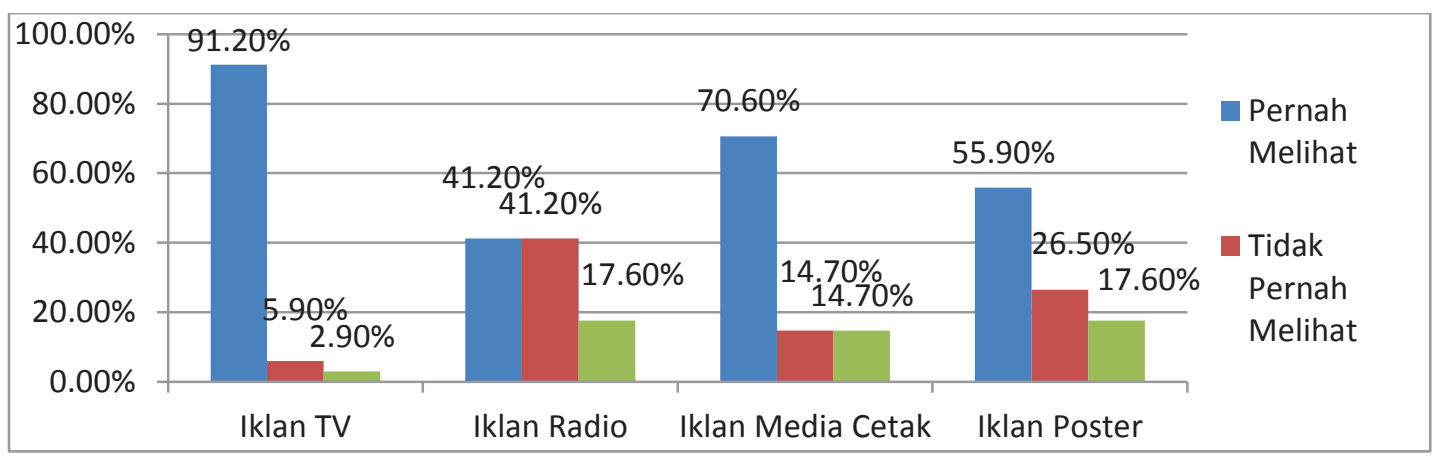

Gambar 10. Persentase Intensitas Masyarakat Melihat Iklan Naura

\section{Promosi Penjualan}

Promosi penjualan yang pernah dilakukan oleh pihak Naura yaitu, pengadaan kuis berhadiah, dan membuat edisi special terkait produk-produk Naura. Dari gambar 11 yang berkaitan dengan respon konsumen tentang kegiatan promosi penjualan produk-produk Naura, 37,1\% responden berpendapat Naura sering mengadakan kuis berhadiah, 34,3\% responden menjawab kadang-kadang, 22,9\% responden menjawab jarang, dan 5,7\% responden menjawab sangat jarang. Sedangkan untuk kegiatan promosi penjualan melalui edisi spesial atau pemberian bonus, $11,4 \%$ responden menjawab sangat sering, 54,3\% menjawab sering, 22,9\% menjawab kadang-kadang, dan 11,4\% responden lainnya menjawab jarang. Dari data tersebut dapat ditarik kesimpulan bahwa diantara 2 (dua) kegiatan promosi penjualan, yang paling sering dilakukan adalah pembuatan edisi spesial atau bonus dari produk-produk Naura. Edisi spesial contohnya adalah CD/DVD dengan tanda tangan dari Naura, atau pemberian bonus merchandise dari pembelian album Naura, dan lain-lain.

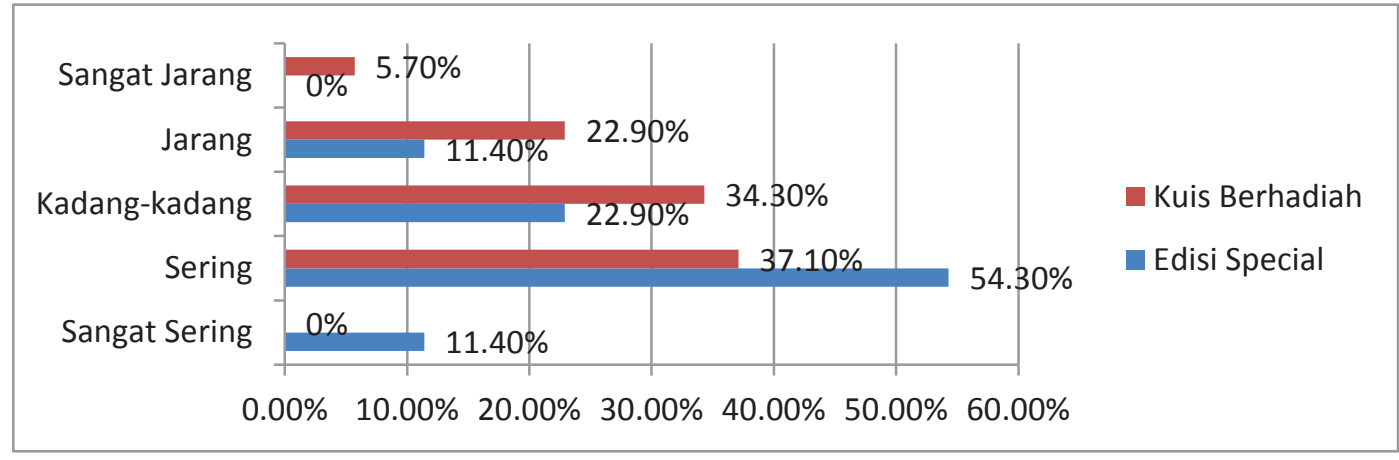

Gambar 11. Persentase Respon Konsumen Terhadap Kegiatan Promosi Penjualan 


\section{Publisitas/Hubungan Masyarakat}

Dari data kualitatif, didapat keterangan bahwa kegiatan publisitas yang dilakukan oleh pihak Naura adalah melalui konferensi pers. Dari gambar 12 dapat dilihat bahwa 60\% repsonden mengetahui pihak Naura pernah mengadakan konferensi pers, dan $40 \%$ responden lainnya tidak mengetahui pihak Naura pernah mengadakan konferensi pers.

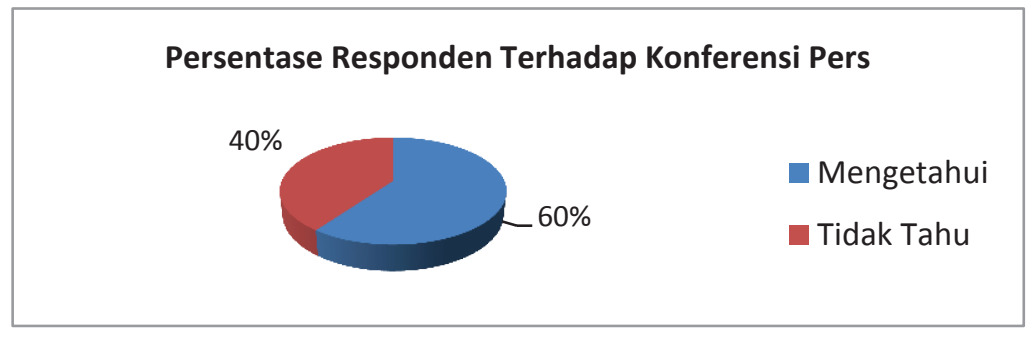

Gambar 12. Persentase Responden Terhadap Konferensi Pers

Dari data kuantitatif yang diperoleh mengenai publisitas dengan 60\% responden menyatakan pernah mengetahui konferensi pers dari Naura, maka data tersebut sesuai dengan data kualitatif yang menyebutkan bahwa pihak manajemen Naura sering mengadakan konferensi pers juga. Namun dalam hal publisitas, manajemen Naura masih perlu peningkatan agar citra yang lebih baik lagi dapat diciptakan. Publisitas lain yang dapat ditempuh misalkan mengikuti kegiatan sosial di masyarakat atau charity dalam kegiatan seni pertunjukan.

\section{Penjualan Perseorangan}

Penjualan perseorangan biasanya dilakukan dalan lingkungan yang kenal atau dekat dengan pihak Naura seperti keluaga, kerabat, mitra atau temen-teman. Tetapi pada saat tertentu Naura sesekali berinteraksi dengan penggemarnya atau Teman Naura bahkan melayani sampai melayani pembelian produk-produknya. Terlihat dari gambar 13 bahwa $68,6 \%$ responden tidak pernah mengalami penjualan perseorangan secara langsung dari pihak Naura, dan hanya $31,4 \%$ responden saja yang pernah mengalaminya.

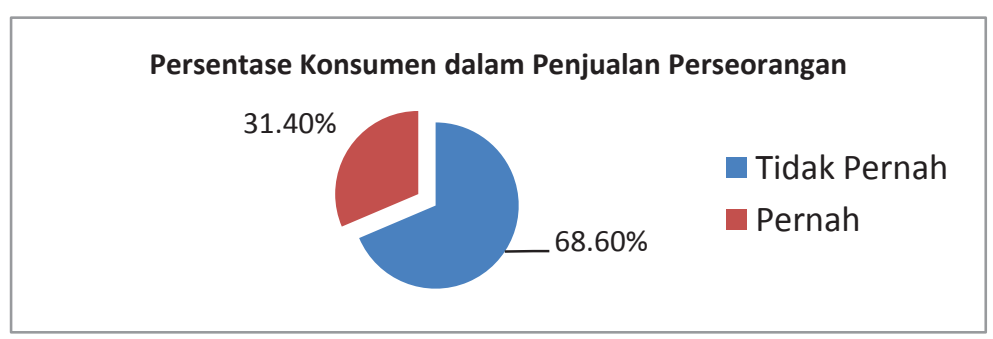

Gambar 13. Persentase Konsumen dalam Penjualan Persoerangan

Penjualan perseoragan dalam dunia musik berbeda dengan penjualan produk-produk lain pada umumnya seperti penjualan produk makanan/souvenir. Dalam dunia musik memiliki tantangan tersendiri karena tidak semua kalangan masyarakat menganggap musik sebagai kebutuhan pokok, sehingga kegiatan penjualan perseorangan tidak semudah melakukan penjualan produk pada umunya, perlunya mengetahui sasaran yang tepat untuk menawarkan produk dari dunia musik. 


\section{Pemasaran Langsung}

Kegiatan pemasaran langsung merupakan kegiatan yang cukup banyak dilakukan oleh pihak Naura. Pemanfaat media sosial misalnya, menjadi salah satu kekuatan untuk mengenalkan Naura dan lagu-lagunya kepada masyarakat luas. Berikut ini data-data terkait sosil media Naura.

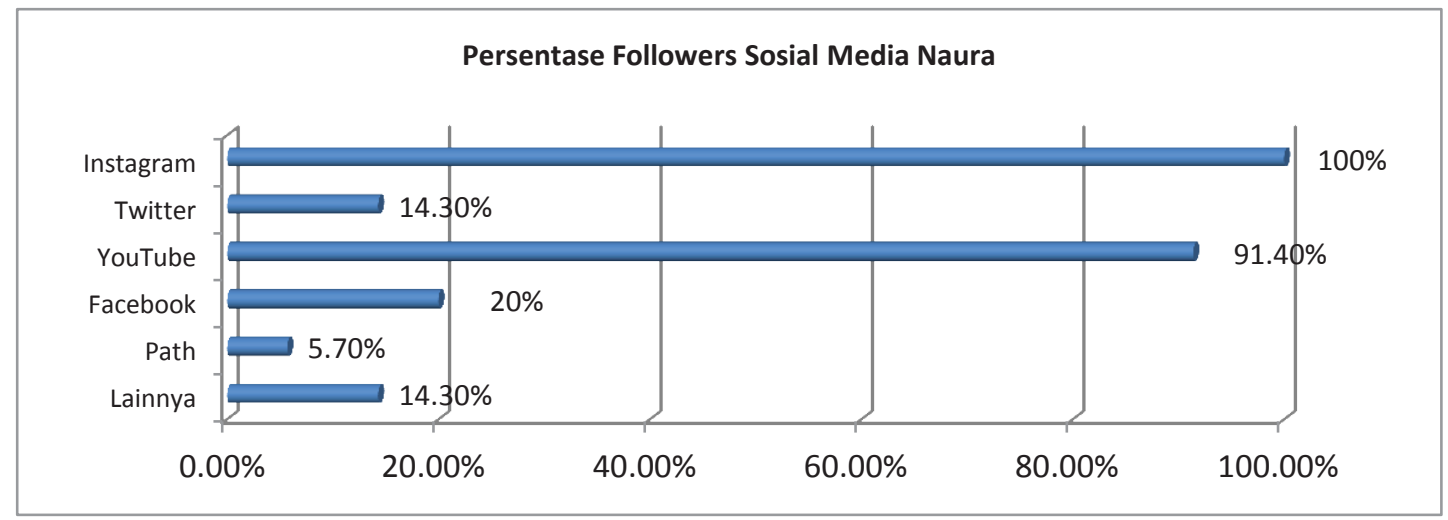

Gambar 14. Persentase Followers Sosial Media Naura

Dari gambar 14 dapat dilihat bahwa followers paling banyak adalah pada akun Instagram dengan persentase 100\% responden, kemudian di urutan ke-2 adalah akun YouTube dengan persentase 91,4\% responden. Berikutnya adalah akun Facebook dengan persentase 20\% responden yang mengikuti. Sedangkan akun twitter dan sosial media lainnya menduduki urutan ke-4 dengan persentase 14,3\% responden dan terakhir adalah akun Parh dengan follower paling sedikit yaitu dengan persentase $5,7 \%$ responden.

Dari pemaparan tersebut, pemasaran dengan menggunakan media sosial merupakan strategi yang paling efektif dintara elemen bauran promosi lainnya karena semua penggemar Naura menggunakan media sosial dengan demikian semua berita terbaru tenntang Naura akan lebih cepat dan lebih mudah diketahui bagi para penggemar Naura.

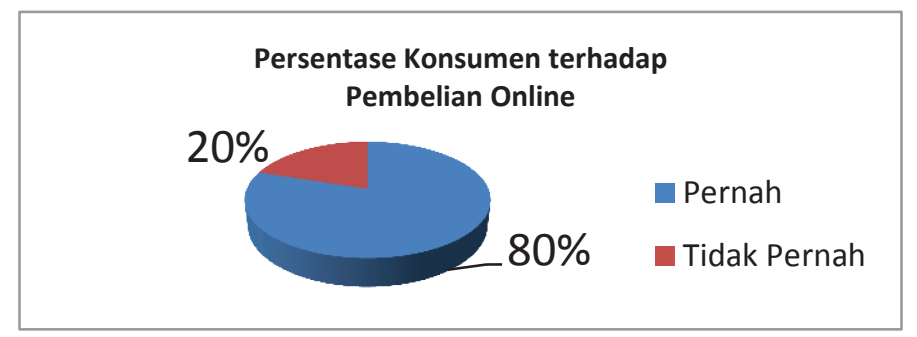

Gambar 15. Persentase Konsumen yang Melakukan Pembelian Online

Selain pemanfaatan sosial media, Naura juga menggunakan jasa jual beli online untuk memudahkan pemasaran produknya, seperti situs belanja blibli.com. Dari gambar 15 dapat dilihat bahwa $80 \%$ responden pernah membeli produk Naura melalui jasa jual beli online dan $20 \%$ responden lainnya tidak pernah melakukan pembelian melalui cara online.

Dari perolehan data kuatitatif mengenai pemasaran langsung yang menampilkan data follower media sosial Naura yang paling banyak adalah Instargram dan 80\% responden pernah melakukan transaksi jual beli online terkait produk Naura, maka data tersebut sesuai 
dengan data kualitatif yang dinyatakan oleh pihak stakeholder dengan pernyataan yang sama, yaitu media promosi utama melalui Instagram dan bekerjasama dengan situs jual beli online.

\section{Kesimpulan}

Manajemen Naura menggunakan seluruh bauran promosi dalam sosialisasi lagu-lagunya. Diantaranya yaitu periklanan, promosi penjualan, publisitas, penjualan perserorangan dan pemasaran langsung. Adapun penjelasannya sebagai berikut: 1)periklanan menggunakan radio melalui program talkshow tentang album Naura dan pemutaran lagu-lagu dan periklanan melalui televisi; 2) promosi penjualan dilakukan dengan cara mengadaan kuis berhadiah, packaging ekslusif dari DVD karaoke album Naura dan Dongeng Naura Card; 3) publisitas atau hubungan masyarakat dilakukan dengan menggelar konferensi pers; 4) penjualan perseorangan sempat dilakukan oleh pihak Naura pada penjualan album pertama; 5) pemasaran langsung merupakan kekuatan utama dari promosi album Naura. Dari single pertama sampai terbentuk album kedua, pihak Naura memaksimalkan promosi melalui media sosial khususnya akun Instagram dan YouTube.

Respon dan tanggapan masyarakat terhadap adanya lagu-lagu dari album penyanyi cilik Naura diambil dari para followers Instagram Naura. Para penggemar Naura memberi konfirmasi yang sama dengan pernyataan stakeholder tentang variable bauran promosi. Dalam hal aksesbilitas lagu-lagu Naura, masyarakat lebih banyak memperoleh lagu-lagu Naura dengan cara mengunduh dari internet dan media sosial yang paling banyak diakses oleh masyarakat adalah Instagram Naura.

\section{Kepustakaan}

A. Sumber Tertulis

Airlangga, Dhiva. 3013. Sosialisasi tentang Pengetahuan Keagamaan oleh Orang Tua Beda Agama Kepada Anaknya (Studi deskriptif di Surabaya) dalam Jurnal Sosial dan Politik. Surabaya : Universitas Airlangga.

Ardipal. 2015. Kembalikan Lagu Anak-anak Indonesia: Sebuah Analisis Struktur Musik dalam Jurnal Panggung Vol. 25 No. 4, Desember

Creswell, John W. 2012. Research Design Pendekatan Kualitatif, Kuantitatif, dan Mixed. Yogyakarta: Pustaka Pelajar.

Hargreaves, David J. Dan Adrian C. North. 2003. Psikologi Sosial Musik (diterjemahkan oleh Djohan Salim). London: Oxford University Press.

Kotler, Philip. And Armstrong, Garry. 2004. Dasar-dasar Pemasaran (edisi kesembilan). Jakarta: PT.Indeks

Kotler, Philip. And Keller, Kevin L. 2009. Manajemen Pemasaran (edisi duabelas). Jakarta: PT. Indeks.

Moleong, Lexy J. 2013. Metodologi Penelitian Kualitatif (Cetakan ke-31). Bandung: PT. Remaja Rosdakarya.

Prier, Karl-Edmund. 1996. Ilmu Bentuk Musik (Cetakan ke-1). Yogyakarta: Pusat Musik Liturgi. 
Privandani,Chandra Eka. 2016. Komunikasi pemasaran album musik "ikrak" oleh band Indie Fisip Meraung dalam Jurnal Program Studi Ilmu Komunikasi Fakultas Ilmu Sosial dan Politik Universitas Sebelas Maret Surakarta

Raharja, Budi. 2009. Efek Musik Terhadap Prestasi Anak Usia Prasekolah: Studi Komparasi Efek Lagu Anak, Dolanan Jawa, dan Musik Klasik dalam Jurnal Cakrawala Pendidikan, Juni 2009, Th. XXVIII, No.2

Rangkuti, Freddy. 2015. Analisis SWOT: Teknik Membedah Kasus Bisnis. Jakarta: PT. Gramedia Pustaka Utama.

Rosmiati, Ana. 2014. Teknik Stimulasi dalam Pendidikan Karakter Anal Usia Dini melalui Lirik Lagu Dolanan dalam Resital Jurnal Pertunjukan Vol. 15 No. 1 Juni

Saladin, Djaslim. 2003. Manajemen Pemasaran, Bandung: Linda Karya.

Sarwono, Jonathan. 2006. Metode Penelitian Kuantitatif dan Kualitatif. Yogyakarta: Graha Ilmu.

Sumanto, 2014. Psikologi Perkembangan Fungsi dan Teori. Yogyakarta: CAPS.

Tjiptono, Fandy. 2008. Strategi Pemasaran. Yogyakarta: CV. Andi Offset.

Tyasrinestu, Fortunata. 2014. Lirik Musikal pada Lagu Anak Berbahasa Indonesia. Yogyakarta: Jurnal Pertunjukan Resital volume 15 No. 2 Desember

B. Sumber Internet

- http://tu.laporanpenelitian.com/2014/11/22.html (diakses pada 25 Januari 2017 pukul 09.00 WIB)

- $\quad$ http://www.kabarebralink.com/2016/01/tokoh-purbalingga-pak-kasur-legenda.html (diakses pada tanggal 26 Januari 2017 pukul 10.15 WIB)

- $\quad$ http://kidnesia.com/Boleh-Tahu/Serba-Serbi/Ibu-Sud-Pencipta-Lagu-Anak-Indonesia (diakses pada tanggal 26 Januari 2017 pukul 11.05 WIB)

- http://www.kompasiana.com/sudah-miskin-apresiasi-di-eliminir-pula-namanya-dariciptaannya_55103935a333110237ba8039 (diakses pada tanggal 16 Februari 2017 pukul $10.45 \mathrm{WIB} /$ )

- $\quad$ http://www.anakmasa90an.com/2015/12/tralala-trilili-rcti-1998.html (diakses pada tanggal 16 Februari 2017 pukul 11.25 WIB)

- $\quad$ http://www.seputarpengetahuan.com/2015/02/10-pengertian-strategi-menurut-para-ahlilengkap.html (diakses pada tanggal 17 Februari 2017 pukul $20.30 \mathrm{WIB}$ )

- $\quad$ http://elib.unikom.ac.id/files/disk1/454/jbptunikompp-gdl-albertuswi-22665-14unikom_a-1.pdf

- $\quad$ http://prosiding.lppm.unisba.ac.id/index.php/sosial/article/viewFile/264/pdf （diakses pada tanggal 19 Mei 2017 pukul 11.53 WIB)

- http://aikamedia.com/2016/12/19/indikator-marketing-communication/ (diakses pada tanggal 19 Mei 2017 pukul $12.18 \mathrm{WIB}$ )

- $\quad$ http://repository.widyatama.ac.id/xmlui/bitstream/handle/10364/599/bab2.pdf? sequence= 5 (diakses pada tanggal 20 Mei 2017 pukul 12.37 WIB)

- http://tukangteori.com/2016/03/teori-sosialisasi-dan-pembentukan-kepribadian.html (diakses pada tanggal 22 Mei 2017 pukul 9.36 WIB) 